\title{
Oxygen saturation instability in suspected covid-19 patients; contrasting effects of reduced $V_{A} / Q$ and shunt.
}

\author{
J.Gareth Jones, \\ Formerly Cambridge Clinical School, Cambridge CB2 OQQ. UK. \\ Present address. Woodlands, Rufforth, York, YO23 4QF, UK. \\ E-mail; johngareth423@btinternet.com
}

\begin{abstract}
.
Patients in the UK at risk of Covid-19 pneumonia, but not needing immediate hospital attention, are to be given pulse oximeters to identify a fall in oxygen saturation ( $\mathrm{SaO} 2$ or SpO2) at home. A recent finding in Covid-19 pneumonia is a dominant reduction in ventilation to perfused alveoli $\left(V_{A} / Q\right)$. A mathematical model of gas exchange was used to predict the effect of shunt or reduced $\mathrm{V}_{\mathrm{A}} / \mathrm{Q}$ on $\mathrm{SaO} 2$ stability inferred from the slope of the $\mathrm{PIO} 2$ vs $\mathrm{SaO} 2$ curve as it intersected the line representing ambient $\mathrm{PIO} 2 . \mathrm{A} \pm 1 \mathrm{kPa}$ variation in $\mathrm{PIO} 2$ predicted a $1.5 \%$ and $8 \%$ change in $\mathrm{SpO} 2$ with $15 \%$ shunt and $0.4 \mathrm{~V}_{\mathrm{A}} / \mathrm{Q}$ respectively. As a consistency check, two patients with pre-existing lung disease and 12 hour continuous SpO2 monitoring breathing air had gas exchange impairment analysed in terms of shunt and reduced $V_{A} / Q$. The patient with $16 \%$ shunt and normal $V_{A} / Q$ had a stable but reduced $\mathrm{SpO} 2$ (circa $93 \pm 1 \%$ ) throughout the $12 \mathrm{hr}$ period. The patient with a $\mathrm{V}_{\mathrm{A}} / \mathrm{Q}$ reduced to 0.48 had SpO2 ranging from $75-95 \%$ during the same period. SpO2 monitoring in suspected covid-19 patients should focus on SpO2 varying $>5 \%$ in 30 minutes. Such instability in at risk patients is not diagnostic of Covid -19 pneumonia but this may be suspected from a dominant reduction in $V_{A} / Q$ if episodic hypoxaemia has progressed from a stable $\mathrm{SpO} 2$.
\end{abstract}

Key words. Covid-19, Respiratory Measurement, Pneumonia, ARDS, VA/Q, Shunt, Oxygen Saturation. 
medRxiv preprint doi: https://doi.org/10.1101/2020.12.17.20248126; this version posted January 6, 2021. The copyright holder for this preprint (which was not certified by peer review) is the author/funder, who has granted medRxiv a license to display the preprint in It is made available under a CC-BY-NC-ND 4.0 International license.

\section{INTRODUCTION.}

200,000 patients in England at risk of complications with Covid-19, but not needing immediate hospitalisation, are to be given pulse oximeters to identify deterioration in oxygen saturation (SpO2) at home,[1]. This is to create "virtual Covid wards" of at risk patients who take SpO2 readings and relate these to their health teams. Mortality risk increases and admission to hospital is indicated if SpO2 falls to $94 \%$ or less,[1].

A new finding may transform thinking about SpO2 monitoring in incipient Covid -19 Adult Respiratory Distress Syndrome (ARDS). This is a dissociation between severe hypoxemia and well-preserved alveolar gas volume in Covid-19 ARDS causing reduced ventilation to perfused alveoli $\left(V_{A} / Q\right)$ with high compliance and radiological sparing. This is virtually never seen in most forms of ARDS where large shunt, extensive lung radio-opacities and low compliance dominate,[2]. A qualitative relationship has been reported between reduced $\mathrm{V}_{\mathrm{A}} / \mathrm{Q}$ in patients with pre-existing lung disease and unstable SpO2 measured during 12 hour periods of continuous monitoring,[3,4]. A model of pulmonary gas exchange is used here to examine the effect of a reduction in $V_{A} / Q$ or increase in shunt on the position and slope of the $\mathrm{PIO} 2$ vs $\mathrm{SpO} 2$ curve as it intersects the line representing $21 \mathrm{kPa} \mathrm{PIO} 2$, i.e breathing air at sea level. From this will be inferred the stability of $\mathrm{SaO} 2$ with changes in distribution of ventilation or shunt. Newly available methods have enabled more precise discrimination of shunt and reduced VA/Q to examine the relationship between these entities and $\mathrm{SpO} 2$ stability from previous studies,[5,6]. It is proposed that SpO2 instability is a sign of reduced $V_{A} / Q$ which may be a diagnostic feature of incipient Covid- 19 ARDS.

\section{BACKGROUND.}

$\mathrm{V}_{\mathrm{A}} / \mathrm{Q}$ and shunt can be derived non-invasively using a computer algorithm to relate SpO2 to inspired oxygen pressure (PIO2) in a $\mathrm{PIO} 2$ vs SpO2 diagram,[4-7]. An unstable $\mathrm{SpO} 2$ is explained by rightward shift of the PIO2 vs SpO2 relationship when $\mathrm{V}_{\mathrm{A}} / \mathrm{Q}$ and shunt change and is shown diagrammatically in Fig 1 . The shape of the oxygen dissociation curve (ODC, red line, i.e. $\mathrm{PaO} 2$ vs $\mathrm{SaO} 2$,) shifted to the right by $\mathrm{PaCO} 2 / \mathrm{R}$ (blue arrow), provides a PIO2 vs SpO2 curve for the normal lung (blue line). Reducing $\mathrm{V}_{\mathrm{A}} / \mathrm{Q}$ shifts this curve further to the right (green arrow and line) and as it crosses the $21 \mathrm{kPa}$ PIO2 line, representing air breathing, its gradient becomes increasingly steep. Small changes in $V_{A} / Q$ (or 
medRxiv preprint doi: https://doi.org/10.1101/2020.12.17.20248126; this version posted January 6, 2021. The copyright holder for this preprint (which was not certified by peer review) is the author/funder, who has granted medRxiv a license to display the preprint in It is made available under a CC-BY-NC-ND 4.0 International license

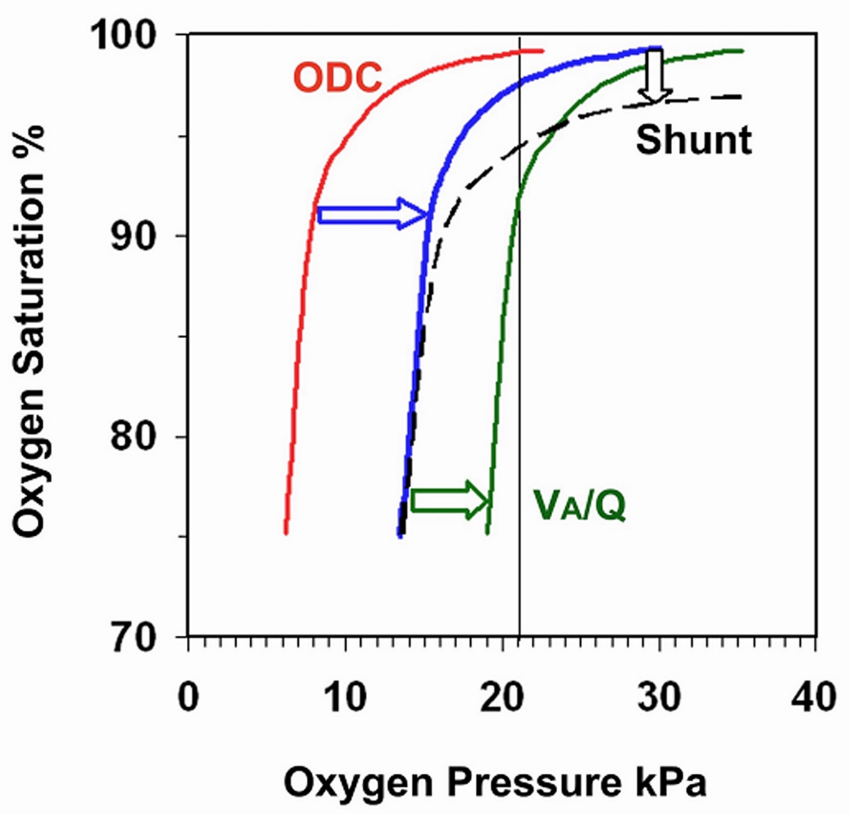

Fig 1. Shows how the Oxygen Dissociation Curve (ODC) determines the shape of the normal lung PIO2 vs SPO2 curve (blue) and the effects of reducing VA/Q (green) or increasing shunt (black). Vertical line is at $21 \mathrm{kPa} \mathrm{PIO}$.

PIO2) cause large changes in $\mathrm{SpO}_{2}$. Increasing shunt bends the curve downwards,[4-6] so that large changes in $\mathrm{PIO}_{2}$ cause small changes in $\mathrm{SpO}_{2}$ emphasising the unreliability of the $\mathrm{PaO}_{2} / \mathrm{F}_{1} \mathrm{O}_{2}$ as an index of oxygen exchange,[8]. An algorithm based on a three compartment lung model was recently developed to analyse the slope of the PIO2 vs SpO2 curve in pre term infants with broncho pulmonary dysplasia,[5-7]. This showed that slope was greatest in those with a homogeneous reduction of $V_{A} / Q$ to circa 0.4 . Slope was considerably less with inhomogeneous pulmonary disease with or without increased shunt.

\section{METHODS}

The effects of reducing $\mathrm{V}_{\mathrm{A}} / \mathrm{Q}$ or increasing shunt on $\mathrm{PIO} 2$ vs $\mathrm{SpO} 2$ curves were derived using a mathematical model of pulmonary gas exchange described by Olszowska andWagner,[9]. Datasets were generated using the equations implemented on a spreadsheet supplied by Dr AJ Olszowka (Model 1). This calculated exact values of arterial oxygen saturation for given values of inspired oxygen concentration. It represented the lungs as three compartments: a pure shunt and two ventilated regions, each with a homogeneous alveolar ventilation-perfusion ratio $\left(\mathrm{V}_{\mathrm{A}} / \mathrm{Q}\right)$. The values of cardiac output, oxygen consumption, haemoglobin concentration, shunt fraction, and the distribution of blood flow and alveolar 
medRxiv preprint doi: https://doi.org/10.1101/2020.12.17.20248126; this version posted January 6, 2021. The copyright holder for this preprint (which was not certified by peer review) is the author/funder, who has granted medRxiv a license to display the preprint in It is made available under a CC-BY-NC-ND 4.0 International license.

ventilation to the ventilated compartments can be set. The perfusion of one compartment whose $V_{A} / Q$ was reduced from 0.85 to 0.3 was set at $90 \%$ of non-shunt flow. A shunt was fixed at $2 \%$ and $\mathrm{PIO} 2$ was varied between 15 and $30 \mathrm{kPa}$, the $\mathrm{SaO} 2$ being derived in each case. Then with $V_{A} / Q$ held at 0.85 and shunt increased stepwise from $2-25 \%$ the $\mathrm{PIO} 2$ was changed over the same range of $\mathrm{PIO} 2$ and $\mathrm{SaO} 2$ derived. The slope of the $\mathrm{PIO} 2$ vs $\mathrm{SaO} 2$ curve as it intersected the $21 \mathrm{kPa} \mathrm{PIO} 2$ line was calculated. To provide a consistency check of this analysis two patients with pre-existing lung disease and 12 hour continuous $\mathrm{SpO} 2$ monitoring from a previous study[3] had their $\mathrm{PIO} 2$ vs SpO2 plots reanalysed with a newly developed algorithm based on a three compartment lung,[5,6].

\section{RESULTS AND DISCUSSION}

The left panels in Fig 2 show the effect on PIO2 vs SaO2 curves of reducing $\mathrm{V}_{\mathrm{A}} / \mathrm{Q}$ or increasing shunt where the vertical line represents $21 \mathrm{kPa}$ PIO2 breathing air at sea level. Reducing $V_{A} / Q$ from normal (circa 0.85 ) shifted the curve gradually to the right so that its
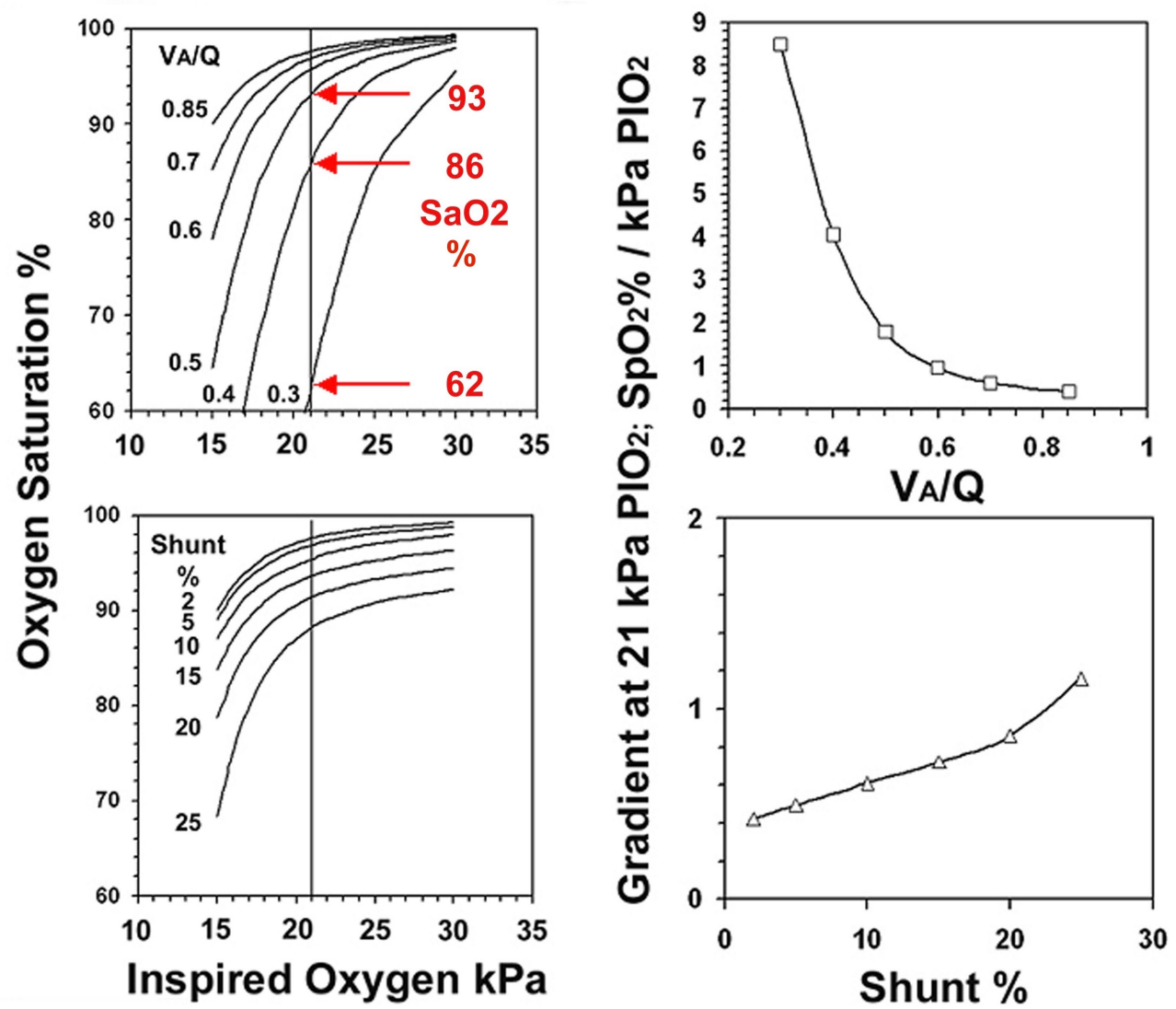

Fig 2. Effect of reducing VA/Q or increasing shunt on the $\mathrm{PIO} 2$ vs $\mathrm{SaO} 2$ curves (left panels) and on the gradient of these curves as they intersect the $21 \mathrm{kPa}$ line (right panel). See text 
medRxiv preprint doi: https://doi.org/10.1101/2020.12.17.20248126; this version posted January 6 , 2021. The copyright holder for this preprint (which was not certified by peer review) is the author/funder, who has granted medRxiv a license to display the preprint in It is made available under a CC-BY-NC-ND 4.0 International license
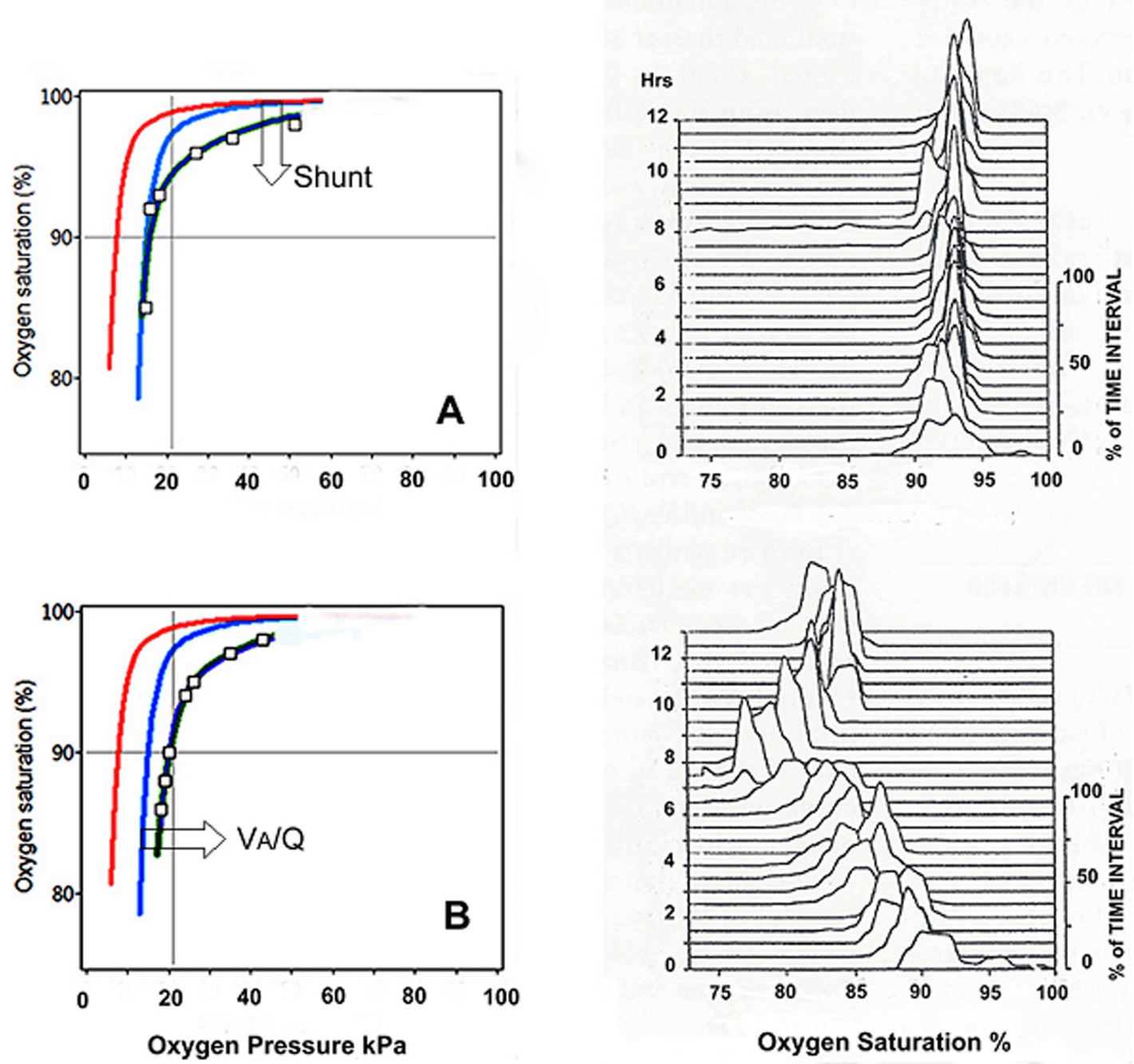

Fig 3. ODC (red) and $\mathrm{PIO} 2$ vs $\mathrm{SpO} 2$ curves for normal lungs (blue) compared to patients A \& B (dk.green), left panels. Pt A curve was displaced downwards by a shunt and in Pt B shifted to the right by reduced VA/Q. Continuous SpO2 monitoring, breathing air, displayed with compressed spectral arrays. Pt A showed superimposed SpO2 peaks throughout the study whereas in B peaks were broad and unstable. Re-analysed and redrawn from Fig 11,[4].

gradient as it intercepted the $21 \mathrm{kPa}$ line became rapidly steeper. Furthermore, as $\mathrm{V}_{\mathrm{A}} / \mathrm{Q}$ fell, the intercept of the curve on the $21 \mathrm{kPa}$ line showed $\mathrm{SaO} 2$ falling abruptly; red arrows indicate a $7 \%$ fall in $\mathrm{SaO} 2$ as $\mathrm{V}_{\mathrm{A}} / \mathrm{Q}$ fell from 0.5 to 0.4 and a $24 \%$ reduction in $\mathrm{SaO} 2$ as $\mathrm{V}_{\mathrm{A}} / \mathrm{Q}$ fell from 0.4 to 0.3 . The panels on the right show the greater effect on gradient of reducing $V_{A} / Q$ than of increasing shunt. The SpO2 will become unstable once $V_{A} / Q$ has fallen to 0.5 ; at a $\mathrm{V}_{\mathrm{A}} / \mathrm{Q}$ of 0.4 a $\pm 1 \mathrm{kPa}$ change in $\mathrm{PIO} 2$ gives an $8 \%$ change in $\mathrm{SpO} 2$ with the likelihood of profound hypoxemia with a further small fall in $V_{A} / Q$. In contrast, with a $15 \%$ shunt, a $\pm 1 \mathrm{kPa}$ change in $\mathrm{PIO} 2$ gives $<2 \%$ change in $\mathrm{SpO} 2$. 
medRxiv preprint doi: https://doi.org/10.1101/2020.12.17.20248126; this version posted January 6, 2021. The copyright holder for this preprint (which was not certified by peer review) is the author/funder, who has granted medRxiv a license to display the preprint in It is made available under a CC-BY-NC-ND 4.0 International license .

To illustrate the clinical effect of $\mathrm{V}_{\mathrm{A}} / \mathrm{Q}$ vs Shunt on $\mathrm{SpO} 2$ stability are two patients with a modest impairment of gas exchange, one with increased shunt the other with decreased $\mathrm{V}_{\mathrm{A}} / \mathrm{Q}$ re-analysed from Fig11 Ref 4. (Fig 3). Left panels show oxygen dissociation (red) and normal lung PIO2 vs SpO2 curves (blue). Patients A and B had dark green PIO2 vs SpO2 curves derived by changing PIO2 stepwise and analysing the resulting PIO2 vs SpO2 data pairs with a new computer algorithm, $[5,6]$. The curve plateau was displaced downwards in A by a moderate shunt (14\%) but not shifted to the right. When breathing air the gradient of curve $\mathrm{A}$ as it intercepted the $21 \mathrm{kPa}$ PIO2 line was 0.5 and similar to the normal lung. In $B$ the whole curve was shifted to the right by the $V_{A} / Q$ reduced to 0.48 . This patient had a shunt of $12 \%$ but the effect on $\mathrm{SpO} 2$ was outweighed by reduced $\mathrm{V}_{\mathrm{A}} / \mathrm{Q}$ increasing curve gradient at the intercept to $2 \% \mathrm{SpO} 2$ per $\mathrm{kPa} \mathrm{PIO} 2$ which is similar to the result of the mathematical model in the right upper panel of Fig 2 .

Compressed spectral arrays (or Waterfall plots) were used to display the continuously measured SpO2 during the 12 hour monitoring periods breathing air. These showed the distribution pattern of $\mathrm{SpO} 2$ in 30 minute intervals, each moving up the page. Patient $\mathrm{A}$ with an increased shunt showed a stable pattern with superimposed peaks varying 1-2\% around the median, closely resembling the normal lung pattern [4], but with a lower than normal median SpO2 circa 93-94\%. In contrast Patient B with reduced $\mathrm{V}_{\mathrm{A}} / \mathrm{Q}$ had broad peaks with $\mathrm{SpO} 2$ drifting downwards from $>95$ to $75 \%$ during the study. Large falls in $\mathrm{SpO} 2$ are consistent with small reductions in $\mathrm{V}_{\mathrm{A}} \mathrm{Q}$ below 0.5 . Compared to the highly unstable $\mathrm{SpO} 2$ with a modest reductions of $\mathrm{V}_{\mathrm{A}} / \mathrm{Q}$ to 0.5 , it would be expected from Fig 2 that a patient with a $25 \%$ shunt breathing air would have a stable saturation down to $88 \% \mathrm{SpO} 2$.

Instability of SpO2 breathing air with $\mathrm{SpO} 2$ varying $>5 \%$ in 30 minutes is a sensitive marker of a reduction in $\mathrm{V}_{\mathrm{A}} / \mathrm{Q}$, e.g. to $<0.5$. The shape of the $\mathrm{P}_{1} \mathrm{O}_{2} \mathrm{Vs} \mathrm{SpO}_{2}$ curve indicates more specifically the nature and magnitude of the underlying gas exchange abnormality; only a pencil and paper are required with $\mathrm{PIO} 2$ varied in three or more steps using a Ventimask,[10] In practice reduced $V_{A} / Q$ and and increased shunt often co-exist in different proportions giving complex effects on curve shape. A computer program plots the curve

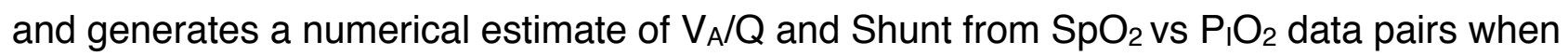
$\mathrm{P}_{1} \mathrm{O}_{2}$ is changed stepwise,[5,6]. 
medRxiv preprint doi: https://doi.org/10.1101/2020.12.17.20248126; this version posted January 6, 2021. The copyright holder for this preprint (which was not certified by peer review) is the author/funder, who has granted medRxiv a license to display the preprint in It is made available under a CC-BY-NC-ND 4.0 International license .

Other groups have reported on SpO2 monitoring of at risk Covid -19 patients in a domestic "virtual ward" setting. One chose a threshold for admission of $2 \%$ less than a $96 \%$ target, [11]. Another did not find such monitoring useful because of variability of implementation, [12] whereas a third reported on remote monitoring of 26 patients after discharge from hospital with Covid-19,[13]. In the latter group there were 5 "alerts" and 4 re-admissions with a median of $91 \% \mathrm{SpO} 2$ and a lowest reading of $82 \%$. None commented on unstable SpO2.

\section{CONCLUSION}

A modest reduction in $V_{A} / Q$ to between 0.5 and 0.4 causes a right shift of the PIO2 vs SpO2 curve and a considerable increase in the gradient of this line as it intersects the $21 \mathrm{kPa}$ line. Small changes in ventilation and/or a further small reduction in $V_{A} / Q$ causes large changes in $\mathrm{SpO} 2$ circa $>4 \%$. While SpO2 instability breathing air is a sign of reduced of $V_{A} / Q$ it is not, per se, diagnostic of Covid -19 pneumonia. SpO2 varying substantially both below and above the $94 \%$ target threshold may be confusing to patients and their health teams. An at risk Covid-19 patient with previously normal SpO2 but develop ing unstable SpO2 with episodes of profound hypoxaemia out of proportion to radiological change may well be compatible with the reduced $V_{A} / Q$ of Covid-19 pneumonia.

\section{ACKNOWLEDGMENTS}

The author thanks Dr A Olszowka, Department of Physiology, University of Buffalo, New York, USA for providing his pulmonary gas exchange program and Mr Jon Brassey, Trip Database, for help in the preparation of this paper.

\section{REFERENCES.}

1. Torjesen I. Covid-19: Patients to use pulse oximetry at home to spot deterioration.

British Medical Journal 2020;371:m4151 I doi: 10.1136/bmj.m4151.

2. Gattinoni, L., Chiumello, D. \& Rossi, S. COVID-19 pneumonia: ARDS or not?. Crit Care 24, 154 (2020). https://doi.org/10.1186/s13054-020-02880-z.

3. Roe P, Jones JG. Causes of oxyhaemoglobin saturation instability in the post operative period. Brit J Anaesth. 1993; 71: 481-487 
medRxiv preprint doi: https://doi.org/10.1101/2020.12.17.20248126; this version posted January 6, 2021. The copyright holder for this preprint (which was not certified by peer review) is the author/funder, who has granted medRxiv a license to display the preprint in It is made available under a CC-BY-NC-ND 4.0 International license .

4. Jones JG, Jones SE. Discriminating between the effect of shunt and reduced VA/Q on arterial oxygen saturation is particularly useful in clinical practice. J Clin Monit 2000; 16: 337-350.

5. Lockwood GG, Fung N, Jones JG. Evaluation of a computer program for non-invasive determination of pulmonary shunt and ventilation-perfusion mismatch. J Clin Monit Comput $2014 ; 28: 581-90$.

6. Jones JG, Lockwood GG, Fung N, et al. Influence of pulmonary factors on pulse oximeter saturation in preterm infants. Arch Dis Child Fetal Neonatal Ed. 2016:101(4):F319-22.

7. Svedenkrans J Stoecklin B, Jones JG et al. Physiology and Predictors of Impaired Gas Exchange in Infants with Bronchopulmonary Dysplasia. Am J Resp Crit Care Med 2019; 200: $471-80.5$

8. Karbing DS, Kjærgaard S, Smith BW, et al. Variation in the $\mathrm{PaO}_{2} / \mathrm{F}_{1} \mathrm{O}_{2}$ ratio with $\mathrm{F}_{1} \mathrm{O}_{2}$ : mathematical and experimental description, and clinical relevance. Crit Care. 2007;11:R118.

9. Olszowka AJ, Wagner PD. Numerical analysis of gas exchange. In: West JB, editor. Pulmonary gas exchange. New York: Academic Press; 1980. p. 263-306.

10. Jones JG, Bakewell SE, Heneghan CPH et al. Profound hypoxemia in pulmonary patients in airline-equivalent hypoxia: roles of VA/Q and shunt. Aviat Space Environ Med 2008; 79:81-6.

11. Inada-Kim M, Chimel FP, Boniface MJ et al Validation of home oxygen saturations as a marker of clinical deterioration in patients with suspected COVID-19 doi: https://doi.org/ $\underline{10.1101 / 2020.11 .06 .20225938}$

12. Vindrola-Padros C, Singh KE, Sidhu MS et al. Remote home monitoring (virtual wards) during the COVID-19 pandemic: a living systematic review doi: https://doi.org/10.1101/2020.10.07.20208587

13. O'Caroll O, MacCann R, O'Reilly A, et al. Remote monitoring of oxygen saturation in individuals with COVID-19 pneumonia.

European Respiratory Journal 2020 56: 2001492; DOI: 10.1183/13993003.01492-2020 